Portland State University

PDXScholar

\title{
Examining Sense of Place for Marginalized Communities in Community Gardens
}

Jocelyn Rodriguez

Portland State University

Follow this and additional works at: https://pdxscholar.library.pdx.edu/honorstheses

\section{Let us know how access to this document benefits you.}

\section{Recommended Citation}

Rodriguez, Jocelyn, "Examining Sense of Place for Marginalized Communities in Community Gardens" (2018). University Honors Theses. Paper 533.

https://doi.org/10.15760/honors.544

This Thesis is brought to you for free and open access. It has been accepted for inclusion in University Honors Theses by an authorized administrator of PDXScholar. Please contact us if we can make this document more accessible: pdxscholar@pdx.edu. 


\section{Introduction}

The objective of this study is to explore how marginalized gardeners feel about their gardens, why they feel that way and to determine what that garden space does for them. Marginalized communities are unable to occupy many spaces and lifestyles due to ethnicity, purchasing power, and mental or physical ability. This study examines relationships with a place where these communities are very active and prominent, and it seeks to understand the role that the gardens have in their lives.

This paper critically examines community garden relationships with particular reference to marginalized communities in Portland, OR. First, we will discuss the existing literature on community gardens, followed by an introduction of the concept of sense of place and how it is being used to study relationships between people and place. From there, I will discuss the demographics of the neighborhoods that the gardens are in to identify the hardships their residents face. Lastly, for my analysis, I review interviews conducted with gardeners and examine their relationship through a sense of place framework.

\section{Literature Review}

\section{Community Gardens}

The national implementation of community gardens began during both World Wars when city lands made available to the public produced $40 \%$ of the vegetables consumed in the US by 1944 (USDA). Since then, research on community gardens suggests a wide range of benefits for both gardeners and the community (Armstrong, 2000). Benefits ranging from reducing local crime (Gold, 1976; Malt 1972; Baker, 1997), empowering residents and building social capital (Bjornson, 1994; Ferris et al., 2001; Kweon et al., 1998; Kuo and Sullivan, 1998; Landman, 1993; Schmelzkopf, 1995), providing a food alternative for urban food insecurity (Hlubik and Hamm, 1994; Pinderhughes, 2003; Rauber, 1997), functioning as urban commons where minority residents collectively produce space to resist or provide alternatives to capitalist social relations (Eizenberg, 2012; Ghose \& Pettygrove, 2014), to being sites of grassroots citizenship practice and place-based community development (Armstrong, 2000; Baker, 2004; Kurtz 2001; Macias 2008; Schmelzkopf 1995; Staeheli et al 2002). Growing literature on community gardens continues to highlight the advantages of community gardens as a form of urban agriculture.

\section{Sense of Place}

Sense of place can be described as the meaning attached to a spatial setting by an individual. Tuan has declared that a place is a center of meaning or field of care that emphasizes human emotions and relationships (1979). Place has also been described as being "much more than a point in space...but takes in the meanings which people assign to that landscape through the process of living in it" (Ryden, 1993). An authentic sense of place is described as "being inside and belonging to your place both as an individual and as a member of the community" (Relph, 1976). For this study, we are going to examine sense of place as an attitude as introduced by Canter (1991). Canter found that by integrating examination of sense of place into three categories: place identity, place dependence, and place attachment; researchers are able to develop a deeper understanding of people's sense of place. 


\section{Case Study}

\section{The Gardens}

Portland Parks and Recreation Community Gardens Program currently has 52 gardens across 23 acres of land for agricultural production. The organization focuses on making public land accessible to community members to grow food and partners with outside organizations that provide education and resources such as starts and seeds for gardeners. Director of the program, Laura Niemi, emphasizes the goal of the program, apart from the logistics of land distribution, is to build a community within the gardens. Creating policies that define expectations of how to be a 'perfect' gardener and good neighbor include what to grow, how to maintain your plot, and garden tool use and care. Additionally, to be able to garden with Portland Parks and Recreation each gardener must complete six service hours which can be completed through activities such as cleanup work or assisting a fellow gardener.

Another part of the process is to have the leaderships of the gardens be reflective of the communities they are serving. This manifests in gardens having multiple volunteer managers with multilingual interpreters hired for community meetings. There they facilitate conversation between gardeners encouraging and enhancing interactions among the users. Every year, the gardens hold various events such as community potlucks, clean-ups, and renewal parties. The purpose is to bring people together and help to identify common projects that everyone can work on. Niemi emphasizes that these events are for gardeners to get to know each other so they will feel welcomed and given opportunities to get involved. The gardens program also offers scholarships for participants that qualify based on their income. All scholarships are granted and the program has unlimited funds for need-based participants (Niemi, 2018).

On the front page of their website the following paragraph is found:

Portland Community Gardens is committed to the overall Citywide vision that race will have no detrimental effect on people of color, refugee and immigrant communities in accessing our community gardens, or from the benefit of our services. We recognize that achieving racial equity will take time, with dedicated leadership and commitment by managers and staff. We acknowledge, understand and encourage celebration of the differences that surround us. Equity, inclusion, and diversity are vital to Portland Parks \& Recreation's ideals and values.

Portland Parks and Recreation supports inclusion and works towards equity in its programming supporting community gardens. They acknowledge that work needs to be done in the city to make sure that all residents feel included and respected.

The other gardens from this study are a part of SnowCap Community Gardens in Gresham.

SnowCap, Suburban Neighborhoods Operation Witness Community Action Program, was established in 1967 after the community of East Multnomah County felt that their basic needs were not being met by governments, agencies, or organizations. Their goal was to assess the real needs of the area and work as a community to meet the needs of the neighborhood, collectively. SnowCap has served 1.4 million people since its formation (SnowCap, 2018). SnowCap's community garden program offers 45 raised bed plots to low-income families and are able to acquire plots with seeds, starts, water, and greenhouse space provided for free. Each year, a beginner gardening class is offered using the "Seed to Supper" curriculum 
developed by the Oregon Food Bank and offers classes from outside organizations as well, such as canning classes from Oregon State Extension Service during the summer and fall.

Included in their mission we find that:

Snow Cap will cross lines of race, religion, national origin, and economic status, hoping to coordinate and act as a barometer, correcting conditions which call for improvement. (SnowCap, 2018)

Here we see that SnowCap also focuses on the uneven and discriminatory actions that many residents face in the area. In accordance with federal law and the US Department of Agriculture Policy, SnowCap is prohibited from discriminating against gardeners. It is made clear in their mission statement that this was their intent. Both of the gardens in this study identify that there is a need for, and are actively trying to be, places where people of all kinds can come and take space and participate in their community

\section{The Demographics}

\begin{tabular}{|l|l|l|l|l|l|l|}
\hline Neighborhoods & $\%$ White & $\%$ Black & $\%$ Asian & $\begin{array}{l}\text { \% Native } \\
\text { American }\end{array}$ & $\begin{array}{l}\% \\
\text { Hispanic }\end{array}$ & $\begin{array}{l}\% \\
\text { On SNAP }\end{array}$ \\
\hline $\begin{array}{l}\text { Rockwood, } \\
\text { Gresham }\end{array}$ & 55 & 6 & 5 & .8 & 27 & 38.3 \\
\hline Cully, Portland & 62 & 18 & 7 & 4 & 20 & 28 \\
\hline $\begin{array}{l}\text { Powellhurst- } \\
\text { Gilbert, Portland }\end{array}$ & 67 & 8 & 15 & 3 & 15 & 42 \\
\hline
\end{tabular}

Figure 1: Demographics of the three neighborhoods where garden relationships were examined (2010 Census; Oregon DHS Office of Forecasting Research \& Analysis).

The subjects interviewed for this study come from three different neighborhoods in the greater Portland area. Each neighborhood shares similar demographics, economic hardships, and need for resources. Ethnically, the communities are all predominately white. However, over the years, these neighborhoods show a steady increase in populations of color. For instance, the 1990 census reported for Rockwood a white population of $91 \%$ which was lowered to $55 \%$ by 2010 (2010 Census). While there is dynamic shift taking place in the demographics of these neighborhoods, it is evident that the marginalized communities are still in the minority.

The neighborhoods presented share another common factor, according to the Oregon DHS Office of Forecasting Research \& Analysis, they are considered 'high poverty hotspots.' These are geographic concentrations of poor residents identified by a census tract or contiguous group of tracts with poverty rates of $20 \%$ or more for two consecutive measurements. The poverty rates used were measured in the Census Bureau's 2009- 2012 and 2008-2012 American Community Survey (ACS). Due to the fact that 
these communities struggle financially, a large percentage are also receiving food assistance. As shown in Figure 1, the neighborhoods range from a $28-42 \%$ dependence on government food aid.

The Supplemental Nutrition Assistance Program (SNAP) provides one in seven Americans with monthly benefits in which they are able to purchase food to be prepared at home (Ziliak, 2016). SNAP is able to alleviate food insecurity for households that do not have a large enough income to allocate $30 \%$ of their net income to purchase an adequate amount of food (Ziliak, 2016). Breyer and Voss-Andreae write that the greater Portland area is known to be marked by 'food mirages,' places where full-service grocery stores appear plentiful, but due to high prices, healthful foods are economically inaccessible for lowincome households. As part of a study on community-based public health in 2011, Everett found that:

...although North Portland has several large grocery stores, Hispanic parents find them expensive and lacking in culturally appropriate foods, and therefore travel long distances to shop in discount supermarkets. We describe this phenomenon as a 'food mirage,' rather than a food desert, and argue that the potential impact on health is similar-managing the challenges of time, distance and cost means infrequent shopping trips and less fresh produce.

As Everett reports, some marginalized residents find themselves having to travel far distances for their produce. Other studies support her findings (Rose and Richards, 2004; Zenk et al., 2009) showing that fruit and vegetable consumption tends to vary inversely with distance to a grocery store. Nationally, SNAP recipients live, on average, 1.8 miles from a full-service grocery store, but travel an average distance of 4.9 miles to purchase their groceries (Ver Ploeg et al., 2010). Additionally, since 1980, the price of produce has increased while the price of energy-dense food, foods that have a high concentration of calories per bite, have decreased (Wendt and Todd, 2011). One study found that with a 10\% increase in the price of soft drinks there would be a 8 to $10 \%$ reduction in consumption and a $10 \%$ price reduction of vegetables would result in a 5.8- 7\% increase of consumption (Andreyeva et al., 2010; Breyer and VossAndreae 2013).

With this data, we are able to see that the communities in which the gardeners are a part of, are places of great economic hardship. They are composed of populations where people of color are in the minority. Economic hardships result in residents, regardless of ethnicity, being given limited access to fresh, nutritious, and whole foods.

\section{Methods}

In order to get interviewees for this study, I contacted the Director of Portland Parks and Recreation and conducted an interview with her. We discussed potential ways that I would be able to communicate with gardeners. Due to the fact that it was winter, I was not likely to be able to interact with people in the gardens themselves. I was able to send informational materials about the study in both English and Spanish via email that was then forwarded out to the community gardeners. From there, gardeners contacted me and we set up meeting times. The second half of the people interviewed from the study were part of the aforementioned SnowCap Gardens. SnowCap hosted a volunteer clean up event over MLK weekend at their gardens. I attended and was put in touch with their coordinator. Gardeners were then put in touch with me if they wanted to be part of the study. 
Six people were interviewed, five gardeners and the Director of the Portland Parks and Recreation Community Gardens program. In total, there were two men and four women ranging from ages 20-65. When selecting people to be interviewed for this study, I was interested in gardeners who belonged to a marginalized group. The gardeners were from self-identified communities of color, lowincome communities, and/or communities with disabilities. Interviews conducted in Spanish have been translated into English by a translator.

\section{Findings}

The purpose of the interviews was for me to be able to share the gardeners' experiences, hardships, and relationships with their community and the gardens. There were very apparent themes throughout the conducted interviews. Food access, health, family, and getting to know their community, were all topics that each of the gardeners felt strongly about when asked about their time in the gardens.

\section{Food Access}

When gardeners were asked why they decided to join the program, they all shared that their reasoning was to increase their food access. For some, that meant they were able to gain access to food from their culture:

'I got involved in community gardens because I am from Mexico and we use tomatillos and jalapenos.' (Adriana)

For others, we see an emphasis on the costs they were able to avoid:

'It saves you on the groceries because you're growing the veggies that you need most and what you use the most as well. You're able to save yourself 10-15 bucks worth of vegetables when you're growing your own. I brought home a bunch of veggies from my garden this year and my mom didn't really have to buy that many from the store.' (Bryan)

'My family, we don't have the money to buy organic stuff, but when we grow it it's more organic than the store anyway.' (Sherma)

A study in Newark, New Jersey shared these findings when they found that across 405 gardens $\$ 450,000$ worth of produce had been harvested (Patel 1991). This allowed garden participants to substantially reduce the amount of money their food expenses.

As Sherma beings to touch on in the quote above, other gardeners go on to emphasize the quality and freshness of their own produce versus that of the store:

I think that more and more people should get into gardening because they need the freshness of the fruits and vegetables. They need to not have to go to the market and purchase something that is handled and possibly contaminated.' (Brian)

'When I would buy vegetables from the store they were not good enough.' (Isabel) 
Increased food access does not affect the gardeners alone, but it also affects their communities. When the gardeners' harvests contain more food than they can consume, they share with extended family as well as friends. A case study in Flint, Michigan found that adults with a household member who participated in a community garden consumed fruits and vegetables 1.4 more times per day than those who did not participate, and they were 3.5 times more likely to consume fruits and vegetables at least 5 times daily (Alaimo, 2008). Sherma shared that she also brings her surplus harvest to local food banks to share with those who are also in need. Here we see that the benefits of belonging to a community garden can reach those outside their own family.

\section{Health}

A main focus for gardeners was also the health benefits that the program allowed them to have. Participants shared how getting involved with the garden improved their health physically. Studies rank gardening as moderate to heavy intensive physical activity and those who participate in gardening also see a favorable change in total cholesterol, HDL cholesterol and systolic blood pressure (Caspersen, 1985):

'I got involved in community gardens because my husband is diabetic and I do it for the exercise.' (Adriana)

Many families with socio-economic barriers also have difficulties in other areas in their lives due to financial and time constraints. Healthcare and physical ailments can often take a backseat when finances are restricted for families. Being able to work in the garden meant that they had exposure to a healthy lifestyle. Prior to working in the program, this opportunity would not have existed:

'I want my family to eat more healthy foods. And aside from that, I have discovered that there are people who need the benefit and influence of a community garden to eat healthier foods.'(Isabel)

Participants also commented on how the garden has affected them mentally. Enabling the gardeners to take a break and focus their efforts in a space, such as this, brings the gardeners a peace of mind:

'The people who come to use the garden need it, they come because they need it and it is healthy for them. I think that it's because people are stressed and battle depression and depression comes and goes, but if they eat healthier then it is better for them.' (Isabel)

'When you're there you're focused on gardening specifically; you're not thinking about what's going on at home. It's one of those things that when you're there you're just engaged in the beauty of the nature and the wonderful idea of what you're doing. Then people talk to you and you talk to them and it's never an argument thing at all it's more like a learning tool or receiving, it's just really nice.' (Brian)

Many authors discuss the benefit of connecting to the natural world through the gardening experience (Hanna, 2000; Kingsley, 2009). Gardens reconnect urban residents with the natural world and its 
functions. With a lack of green spaces in many cities, today residents have few opportunities to connect with nature.

\section{Community}

As Brian stated previously, the most prevalent topic discussed among the gardeners was the sense of community felt while working in the garden. Gardeners reflected on the friendships and relationships built. Throughout these excerpts, we also see an emphasis on helping your fellow gardener and how learning from each other has had a role in developing these relationships:

'In the community, we are a bunch of girlfriends above everything, and in the summer there are all different kinds of people. In the winter, we make friends we talk to each other.' (Adriana)

'They're definitely there for food supplements but there's also the comradery with the family and friends have you seen my garden?! So on and so forth.' (Brian)

'You make long-term friendships with people and you get to know them in a different way and get to know what they're good at you can help them with what you're good at so you can help each other.' (Sherma)

Being able to express yourself was also very important for gardeners. Participants saw the program as a safe space where they were not judged by others or turned away. For some, the garden offers a space where they can be accepted and supported for being who they are:

'It gets people out to be with people who have the same interest as them and have the same needs as them and there's no one there to judge like oh you can't afford to buy this or that because we're all together and all in a sense of need.' (Sherma)

'I want to stay connected to this garden. I like the people there they don't judge me for what I am, who I am, they like me for who I am. With me being autistic I don't find very many people who are like that that can tolerate me. Other people see me as weird, an oddball, or somebody who's like a pest and that just means people don't understand. That's just how I am. That's how a lot of autistic kids are and they're not willing to accept, but these people I love them because they accept me for who I am for what I am and for my disability. They make me feel very welcome there; they have a sign all religions all ethnics all race including those with disabilities are all safe and welcome.' (Bryan)

As Bryan and Sherma express, by providing a space for residents to meet other people and socialize, studies show that community gardens increase social networks, enhancing social support (Armstrong, 2000). Gardens act as a space where social networks can develop by being a place where people can communicate, socialize, and gain support from others in the area, where prior to engagement they had felt isolated (Kingsley, 2009). 
Within the commentary, community gardeners began to discuss just how many different types of people were involved:

'There are all types of people in the program, some who don't know how to read, some with careers, some are people who live alone, people who have a family. There is a lot of diversity, people from other countries.' (Isabel)

'Whenever I come across a gardener I get to meet new people. I got to make new friends and even learn some things from people that I didn't think I could actually do with my garden. You get to learn something new about certain people from a different culture. That's what I like about being around SnowCap you learn new stuff like that and there's always something new that's gonna come up you just don't know when. It brings people together with different race, different backgrounds, different cultures, not only to do their own gardens but to help one another.' (Bryan)

'There have been a lot of immigrants that are part of the community up there of various color and decent and I've met several and I've had a wonderful time learning from them what they do and so it's really neat to just see what everybody's special thing they like to do and plant is.' (Brian)

A study on a community garden in Illinois had similar findings. The community garden provided disenfranchised individuals with opportunities to join a group effort. The whole group experience can be more about the community and the company shared than the act of gardening itself. Gardens offer a place where people can gather, network, and identify together as residents of a neighborhood (Glover, 2003; Kingsley, 2009).

\section{Family}

A final recurring theme throughout the interviews was that it helped gardeners to enhance family togetherness by teaching, spending time together, or bettering their environment:

'It's great working with people I take my kids I take my grandkids it's a fun time out. We usually stop and get some pop afterward because we worked hard gardening and pulling weeds. It's a family thing, my nephew is 33 and he and I have been doing it together now for three years and we just go up there together and just enjoy and talk and get excited about what you see we walk around the garden and see what everyone else is doing get more ideas, water people stuff if it looks like it's getting dry. It's a community thing we feel that way so we walk around and check on stuff.' (Brian)

"It's something fun and I can spend time with my family while doing it. I take my nephew my sister in law who has her own plot and my little sister. My little nephew and my little sister they just love going to the garden they ask all the time 'when are we going when are we going' they do a lot of the planting and harvesting so it's really nice to see' (Sherma) 
Community gardens are often able to improve the social environment for both adults and children by providing them with recreational space and activities (Riddell, 1993; Severson 1987). These gardens, as we see above are used by adults to teach children and introduce them to natural processes of the land through cooperation and collective effort (Keller, 1994; Kurtz, 2001). One study in Minneapolis focusing on urban youth shows that participants in community gardening programs have a better understanding of the food system, the gardening process, and healthy vs unhealthy foods compared to youth that did not participate (Lautenschlager \& Smith, 2007). This shows that gardening educates and influences people to make healthier life decisions.

When thinking about her family, Isabel reflects an aspect very important to sense of place.

'I think that there are people who believe that being in the program is the right thing to do. It's the responsibility that we have as humans to take care of the planet, for humanity, for our families that is what I believe.' (Isabel)

She relates that by gardening she is able to have a deeper connection with the land. She sees it as the duty of the people to have a bond with the Earth and to be a caretaker of the land we live on and redeem goods from. In the following section, we will further survey the environmental attitudes of gardeners.

\section{Analysis}

For my analysis, I will be using a sense of place framework to better understand the gardeners and their relationship with their community garden. The framework I used was created by Jorgensen and Stedman in their 2001 Sense of Place study. They describe sense of place as both an attitude and a meaning that is attached to a spatial setting by a person or group. Their framework allows researchers to measure attitudes towards spatial settings in order to discover how people perceive their environment and to identify how that contributes to their wellbeing (Jorgensen \& Stedman).

There were three categories of relationships with place that the gardeners were asked to reflect upon as part of the interview: place dependence, place attachment, and place identity. Place identity examines individual's relationship between themselves and the place; place attachment examines the emotional connection between the individual and their environment; and place dependence seeks to determine the strength of the relationship by prioritization of the place over others. Each category includes four different statements and the participants were asked to choose the statement that they felt best described their relationship with their community garden. Below are the results of the survey:

Place Identity

1.) Everything about my community garden is a reflection of me. Adriana

2.) My community garden says very little about who I am.

3.) I feel that I can really be myself at my community garden. Bryan, Sherma

4.) My community garden reflects the type of person I am. Brian, Isabel

Place Attachment

1.) I feel relaxed when I'm at my community garden. Brian

2.) I feel happiest when I'm at my community garden. Bryan, Sherma, Adriana, Isabel 
3.) My community garden is my favorite place to be.

4.) I really miss my community garden when I'm away from it for too long.

Place Dependence

1.) My community garden is the best place for doing the things that I enjoy most. Bryan, Sherma, Adriana, Isabel

2.) For doing the things that I enjoy most, no other place can compare to my community garden.

3.) My community garden is not a good place to do the things I most like to do. Brian

4.) As far as I am concerned, there are better places to be than at my community garden.

Both place attachment and place dependence four out of the five gardeners made the same selection in regard to their relationship with their community garden. For place attachment, gardeners in this study express that they feel happiest when they are at their community garden. Participants go to their garden as the place where they can spend the most enjoyable times of their day, week, etc. This is a space that brings joy, pleasure, and a sense of well-being into their life. For place dependence, most of the participants feel that their community garden is the optimum location for doing the things they enjoy the most. This category shows, that if given the choice over all other places where they can participate in various activities, they would choose their garden to spend their time.

While place attachment and dependence show the relationship between a person and place, place identity gives us an idea of how the garden is or is not a reflection of themselves. Sherma and Bryan, who shared earlier on judgment within the garden, chose the option which stated that they feel they can really be themselves at the community garden. While other benefits were mentioned by both gardeners, here we can see what impacts them the most. For them, the space acts as a haven where they feel comfortable and accepted.

The last two statements that the gardeners chose appear to be very similar in meaning. Adriana and Brian believe that their garden reflects the type of person they are. These two gardeners are actually the ones who have participated in gardening the longest, one for 17 years and the other for 50 years. Isabel is helping to establish a community garden at her local church as well as volunteering at the local food bank. Brian held a volunteer coordinator position before retirement and is also active in his local local government. Both of these gardeners are heavily invested in community engagement. Their dedication in the garden parallels who they are outside in the community of Portland.

The last option chosen was 'everything about my garden is a reflection of me.' Here we see that their garden is in essence, a part of them. Adriana, in her interview, emphasized that she had worked for four years to get her plot to be exactly the way she wanted it. This speaks directly to her dedication, intent, and purpose. She also was the only gardener to more diversity in the gardens program. She mentioned how she wishes the garden had the room to host more families and that there are many families in need of help on the waiting list. She was concerned with the low resources the neighborhood has to offer and also touched on that fact that while there is some diversity within her garden she still wants to see more people from more places. 


\section{Conclusion}

The gardeners collectively believed that these are places they identify with, where they spend the most rewarding time, and where they continue to choose to be. The interview process gave insight on interpersonal dynamics and personal gain, while the survey gave a more intimate account. Community gardens offers members what most other spaces cannot. Here they find security in terms of resources and peace of mind. They form connections with people they often would not have the opportunity to connect with otherwise. The shared interest of gardening has given marginalized peoples a place to come together, share their experiences, knowledge, and compassion with each other. These are spaces where gardeners feel safe and welcome. Gardeners look forward to spending their time in these community spaces. With opportunity and tools, they are able to better their financial, health, and social well-being. For marginalized communities, we see that this setting allows them to cultivate a strong sense of place, enabling them to better themselves and their community. 


\section{References}

Alaimo, Katherine, et al. "Fruit and vegetable intake among urban community gardeners." Journal of nutrition education and behavior 40.2 (2008): 94-101.

Andreyeva, Tatiana, Michael W. Long, and Kelly D. Brownell. "The impact of food prices on consumption: a systematic review of research on the price elasticity of demand for food." American journal of public health 100.2 (2010): 216-222.

Armstrong, Donna. "A survey of community gardens in upstate New York: Implications for health promotion and community development." Health \& place 6.4 (2000): 319-327.

Baker, Lauren E. "Tending cultural landscapes and food citizenship in Toronto's community gardens." Geographical Review 94.3 (2004): 305-325.

Baker, Russ. "Where the sidewalks end, urban gardens patches of paradise from vacant lots." Hope, Humanity Making a Difference Apr (1997): 16-23.

Bjornson, Marti Ross. "Greenlining: Chicago's urban community gardens build bridges of access to remove social, political, and economic barriers." Unpublished master's thesis, Northwestern University (1994).

Breyer, Betsy, and Adriana Voss-Andreae. "Food mirages: Geographic and economic barriers to healthful food access in Portland, Oregon." Health \& Place 24 (2013): 131-139.

Burnham, Michael. "New census data show Portland's high-poverty pockets." Metropolitan Knowledge Network (2010).

Canter, David. "Understanding, assessing, and acting in places: Is an integrative framework possible?." Environment, cognition, and action (1991).

Caspersen, Carl J., et al. "The prevalence of selected physical activities and their relation with coronary heart disease risk factors in elderly men: the Zutphen Study, 1985." American journal of Epidemiology 133.11 (1991): 1078-1092.

Cruz, Isabel. Personal Interview. 24 Jan. 2017

Derickson, Kate Driscoll. "Urban geography II: Urban geography in the Age of Ferguson." Progress in Human Geography 41.2 (2017): 230-244.

Eizenberg, Efrat. "Actually existing commons: Three moments of space of community gardens in New York City." Antipode44.3 (2012): 764-782. 
Everett, Margaret. "Practicing Anthropology On A Community-Based Public Health Coalition: Lessons From Heal." Annals Of Anthropological Practice35.2 (2011): 10-26.

Ferris, John, Carol Norman, and Joe Sempik. "People, land and sustainability: Community gardens and the social dimension of sustainable development." Social Policy \& Administration 35.5 (2001): 559-568.

Ghose, Rina, and Margaret Pettygrove. "Urban community gardens as spaces of citizenship." Antipode 46.4 (2014): 1092-1112.

Gilmore, Brian. Personal Interview. 20 Jan. 2017

Glover, Troy D. "The story of the Queen Anne Memorial Garden: Resisting a dominant cultural narrative." Journal of Leisure Research 35.2 (2003): 190-212.

Gold, Seymour M. "Social benefits of trees in urban environments." International journal of environmental studies10.1 (1976): 85-90.

Govea, Adriana. Personal Interview. 26 Jan. 2017

Hanley, Sherma. Personal Interview. 20 Dec. 2017

Hanna, Autumn K., and Pikai Oh. "Rethinking urban poverty: a look at community gardens." Bulletin of Science, Technology \& Society 20.3 (2000): 207-216.

Harris, Elise. "The role of community gardens in creating healthy communities." Australian Planner 46.2 (2009): 24-27.

Hébert, Alison. "Beyond" Rockhood"-Stigma, Diversity, and Renewal in a Suburban Portland Neighborhood." (2013).

Hlubik, William T., and Michael W. Hamm. "221 Measuring The Impact Of A Community Gardening Program." HortScience 29.5 (1994): 461-461.

Holland, Leigh. "Diversity and connections in community gardens: a contribution to local sustainability." Local Environment 9.3 (2004): 285-305.

Jorgensen, Bradley S., and Richard C. Stedman. "A comparative analysis of predictors of sense of place dimensions: Attachment to, dependence on, and identification with lakeshore properties." Journal of environmental management 79.3 (2006): 316-327.

Keller, T "From rubble to roses. American Nurseryman. Vol 179 (1994) 44-47. 
Kingsley, Jonathan 'Yotti, Mardie Townsend, and Claire Henderson-Wilson. "Cultivating health and wellbeing: members' perceptions of the health benefits of a Port Melbourne community garden." Leisure Studies 28.2 (2009): 207-219.

Kuo, Frances E., et al. "Fertile ground for community: Inner-city neighborhood common spaces." American Journal of Community Psychology 26.6 (1998): 823-851.

Kurtz, Hilda. "Differentiating multiple meanings of garden and community." Urban Geography 22.7 (2001): 656-670.

Kweon, Byoung-Suk, William C. Sullivan, and Angela R. Wiley. "Green common spaces and the social integration of inner-city older adults." Environment and Behavior 30.6 (1998): 832-858.

Landeman, R. "Creating community in the city: Cooperatives and community gardens in Washington, $\mathrm{DC}$;

Malakoff, D.(1999). What good is community greening?; Kuo, F., and Sullivan, W.(2001). Environment and crime in the inner city: Does vegetation reduce crime?"." Environment and Behavior33 (1993): 343.

Lautenschlager, Lauren, and Chery Smith. "Understanding gardening and dietary habits among youth garden program participants using the Theory of Planned Behavior." Appetite49.1 (2007): 122-130.

Macias, Thomas. "Working toward a just, equitable, and local food system: The social impact of Community-Based agriculture." Social science quarterly 89.5 (2008): 1086-1101.

Malt, Harry Lewis. An analysis of public safety as related to the incidence of crime in parks and recreation areas in central cities. Harold Malt Associates, (1972).

McClintock, Nathan. "Radical, reformist, and garden-variety neoliberal: coming to terms with urban agriculture's contradictions." Local Environment 19.2 (2014): 147-171.

Niemi, Laura. Personal Interview. 18 Dec. 2017

Oregon DHS Office of Forecasting, Research, \& Analysis. High Poverty Hotspots: East Portland, Multnomah County (2015).

Oregon DHS Office of Forecasting, Research, \& Analysis. High Poverty Hotspots: Gresham Area, Multnomah County (2015).

Oregon DHS Office of Forecasting, Research, \& Analysis. High Poverty Hotspots: Portland Airport Area, Multnomah County (2015).

Parasecoli, Fabio. "Food, identity, and cultural reproduction in immigrant communities." Social Research: An International Quarterly 81.2 (2014): 415-439. 
Patel, Ishwarbhai C. "Gardening's socioeconomic impacts." Journal of Extension 29.4 (1991): 7-8. Pinderhughes, Raquel. "Poverty and the environment: The urban agriculture connection." Natural assets: Democratizing environmental ownership (2003): 299-312.

Pudup, Mary Beth. "It takes a garden: Cultivating citizen-subjects in organized garden projects." Geoforum 39.3 (2008): 1228-1240.

Rauber, Paul. "Cultivating our cities." Sierra 82.3 (1997): 19-21.

Relph, Edward. Place and placelessness. Vol. 1. Pion, (1976).

Riddell, J. "Beyond gardening: Building strong communities through urban gardening." Community Greening Review 3 (1993): 4-9.

Rose, Donald, and Rickelle Richards. "Food store access and household fruit and vegetable use among participants in the US Food Stamp Program." Public health nutrition 7.8 (2004): 1081-1088.

Ryden, Kent C. Mapping the invisible landscape: Folklore, writing, and the sense of place. University of Iowa Press, (1993).

Sbicca, Joshua. "Growing food justice by planting an anti-oppression foundation: opportunities and obstacles for a budding social movement." Agriculture and Human Values29.4 (2012): 455-466.

Schmelzkopf, Karen. "Urban community gardens as contested space." Geographical review (1995): 364381.

Severson, R. "United we sprout: A Chicago community greening story." The meaning of gardens : idea, place, and action: Proceeds (1987)

Slocum, Rachel, Kirsten Cadieux, and Renata Blumberg. "Solidarity, space, and race: toward geographies of agrifood justice." justice spatiale-spatial justice 9 (2016)

Snowcap Community Charities. http://www.snowcap.org/ ( 2018)

Staeheli, Lynn A., Don Mitchell, and Kristina Gibson. "Conflicting rights to the city in New York's community gardens." GeoJournal 58.2-3 (2002): 197-205.

Staeheli, Lynn A. "Globalization and the scales of citizenship." Geography Research Forum. Vol. 19. (2016).

Tuan, Yi-Fu. "Space and place: humanistic perspective." Philosophy in geography. Springer, Dordrecht, (1979). 387-427. 
U.S. Department of Agriculture, "The Facts About 1945 Victory Gardens," Folder 13, Box 30, Defense Council Records, OSA (1945).

Vaske, Jerry J., and Katherine C. Kobrin. "Place attachment and environmentally responsible behavior." The Journal of Environmental Education 32.4 (2001): 16-21.

Ver Ploeg, Michele, ed. Access to affordable and nutritious food: measuring and understanding food deserts and their consequences: report to Congress. Diane Publishing, (2010).

Wendt, M., and J. E. Todd. "The Effect of Food and Beverage Prices on Children's Weights. Washington: US Department of Agriculture." Economic Research Service (2011).

Woods, Bryan. Personal Interview. 20 Jan. 2017

Zenk, Shannon N., et al. "Neighborhood retail food environment and fruit and vegetable intake in a multiethnic urban population." American Journal of Health Promotion 23.4 (2009): 255-264.

Ziliak, James P. "Modernizing SNAP Benefits." Policy Proposal 6 (2016). 